\title{
Short-term impact of crop diversification on soil carbon fluxes and balance in rainfed and irrigated woody cropping systems under semiarid Mediterranean conditions
}

\author{
María Martínez-Mena • Carolina Boix-Fayos • Efrain Carrillo-López • \\ Elvira Díaz-Pereira · Raúl Zornoza • Virginia Sánchez-Navarro • \\ Jose A. Acosta $\cdot$ Silvia Martínez-Martínez $\cdot$ María Almagro
}

Received: 27 March 2021 / Accepted: 21 July 2021 / Published online: 21 August 2021

(C) The Author(s) 2021, corrected publication 2022

\begin{abstract}
Purpose Diversification practices such as intercropping in woody cropping systems have recently been proposed as a promising management strategy for addressing problems related to soil degradation, climate change mitigation and food security. In this study, we assess the impact of several diversification practices in different management regimes on the main carbon fluxes regulating the soil carbon balance under semiarid Mediterranean conditions.

Methods The study was conducted in two nearby cropping systems: (i) a low input rainfed almond (Prunus dulcis Mill.) orchard cultivated on terraces and (ii) a levelled intensively irrigated mandarin (Citrus reticulata Blanco) orchard with a
\end{abstract}

Responsible Editor: Zucong Cai.

Supplementary Information The online version contains supplementary material available at https://doi. org/10.1007/s11104-021-05101-w.

M. Martínez-Mena $(\bowtie) \cdot$ C. Boix-Fayos ·

E. Carrillo-López · E. Díaz-Pereira · M. Almagro

Centro de Edafología y Biología Aplicada del Segura,

CSIC, Campus Universitario de Espinardo, Murcia, Spain

e-mail: mmena@cebas.csic.es

R. Zornoza · V. Sánchez-Navarro · J. A. Acosta ·

S. Martínez-Martínez

Sustainable Use, Management and Reclamation of Soil and Water Research Group, Department of Agricultural Science, Universidad Politécnica de Cartagena, Paseo Alfonso XIII 48, 30203 Cartagena, Spain street-ridge morphology. The almond trees were intercropped with Capparis spinosa or with Thymus hyemalis While the mandarin trees were intercropped with a mixture of barley and vetch followed by fava bean. Changes caused by crop diversifications on $\mathrm{C}$ inputs into the soil and $\mathrm{C}$ outputs from the soil were estimated.

Results Crop diversification did not affect soil organic carbon stocks but did affect the carbon inputs and outputs regulating the soil carbon balance of above Mediterranean agroecosystems. Crop diversification with perennials in the low-input rainfed woody crop system significantly improved the annual soil $\mathrm{C}$ balance in the short-term. However, crop diversification with annual species in the intensively managed woody crop system had not effect on the annual soil C balance.

Conclusions Our results highlight the potential of intercropping with perennials in rainfed woody crop systems for climate change mitigation through soil carbon sequestration.

Keywords Intercropping - Agricultural practices · Soil $\mathrm{CO}_{2}$ emissions $\cdot$ Eroded carbon $\cdot$ Plant carbon inputs $\cdot$ Carbon cycle

\section{Introduction}

Agriculture and land use change account for $23 \%$ of total anthropogenic greenhouse gas (GHG) emissions (IPCC 
2019), while $\mathrm{CO}_{2}$ is responsible for half of annual global emissions (Smith et al. 2014). Furthermore, agriculture expansion and intensification are considered major drivers of soil loss and degradation by accelerating soil erosion rates and speeding up the mineralization of soil organic matter (Xiao et al. 2018). Several studies have found that the soil mobilization and deposition by erosion in agricultural soils under intensive management can significantly alter the global carbon and nutrient cycle (Quinton et al. 2010) and consequently, modify inputs and outputs of soil organic carbon (SOC), altering the natural $\mathrm{C}$ balance of terrestrial ecosystems and increasing GHG emissions to the atmosphere (Aguilera et al. 2015; Amundson et al. 2015). However, the literature related to soil carbon dynamics and climate change provides contradictory results in relation to the potential of agricultural practices to increase carbon sequestration in soils while mitigating GHG emissions (Abbas et al. 2020). The most common sustainable agricultural practices to maintain existing SOC stocks and restore SOC stocks in carbon-depleted soils include reducing tillage intensity and frequency, growing cover crops, the application of compost or manure, and crop residue retention (Hillel and Rosenzweig 2011; Hutchinson et al. 2007; Paustian et al. 2016; Zahra et al. 2016). In this sense, crop diversification practices such as intercropping in woody cropping systems have recently been proposed as a promising management strategy to simultaneously address global environmental challenges such as soil degradation, climate change mitigation and food security (Bossio et al. 2020; Ruiz et al. 2020; Tamburini et al. 2020). In particular, the potential of intercropping for restoring SOC losses derived from the conversion of native ecosystems to croplands in Mediterranean environments has been demonstrated (Aguilera et al. 2013; Almagro and Martínez-Mena 2014; Pardo et al. 2017; VicenteVicente et al. 2016). According to the estimations of Almagro and Martínez-Mena (2014), SOC losses as a consequence of changes in land use, particularly those arising from the conversion of Mediterranean forests and shrublands to woody crop systems, could be compensated after 20 years of intercropping with green manure.

Long-term monitoring is an efficient tool for accurately assessing SOC changes related with agricultural practices. However, short-term estimations of the carbon inputs and outputs occurring in a given agroecosystem after a given management practice has been adopted can provide an early assessment of net SOC balances, thus anticipating decisions on agriculture management. More specifically, if the annual amounts of carbon entering the soil due to the cultivation of other crops with the main crop (crop diversification) exceed the carbon losses through $\mathrm{CO}_{2}$ emissions to the atmosphere and erosion, the SOC balance will be positive and SOC sequestration will be achieved in the short term. However, if the opposite occurs, organic carbon is being lost from the soil system (Almagro et al. 2017).

To date, numerous studies have examined the effect of intercropping on soil erosion, carbon sequestration and soil $\mathrm{CO}_{2}$ emission rates in Mediterranean woody cropping systems, but separately (Aguilera et al. 2013; Morugan-Coronado et al. 2020; Pardo et al. 2017; Vicente-Vicente et al. 2016;). However, to the best of our knowledge, little research has focused on assessing the impacts of crop diversification on the main carbon fluxes regulating the soil carbon balance, including the carbon mobilized by erosion, under two contrasting management regimes (i.e., low-input rainfed and high-input irrigated cropping systems) under semiarid Mediterranean conditions.

The overall aim of this work was to assess the short-term effect of crop diversification on the soil carbon balance of a rainfed and an irrigated woody crop system under semiarid Mediterranean conditions. We focused in the alley between rows soil surface since inter-tree rows occupy around $85-90 \%$ of the total area in these cropping systems. The specific objectives were: (i) to characterize soil carbon inputs and outputs in order to estimate the soil carbon balance under two contrasting agricultural management regimes; and (ii) to assess the impacts of crop diversification on the major components affecting the soil carbon balance under low-input rainfed and high-input irrigated woody cropping systems.

\section{Material and methods}

Study site description and experimental design

The study was conducted in two nearby cropping systems located in the Region of Murcia (SE Spain): i) an organic rainfed almond (Prunus dulcis Mill.) crop cultivated on terraces $\left(37^{\circ} 57^{\prime} 31^{\prime \prime} \mathrm{N}, 0^{\circ} 56^{\prime} 17^{\prime \prime} \mathrm{W}\right.$; 
$167 \mathrm{~m}$ a.s.l., and ii) a levelled irrigated mandarin (Citrus reticulata Blanco) crop with street-ridge morphology ( $37^{\circ} 57^{\prime} 33^{\prime \prime} \mathrm{N}, 0^{\circ} 56^{\prime} 13.8^{\prime \prime} \mathrm{W}$; 155 m.a.s.l. (Fig. 1). The study area is characterized by a semiarid Mediterranean climate, with warm dry summers and relatively cold wet winters. The annual precipitation and air temperature average $231 \mathrm{~mm}$ and $17.5{ }^{\circ} \mathrm{C}$, respectively. The mean potential evapotranspiration reaches $1300 \mathrm{~mm} \mathrm{yr}^{-1}$ (calculated by the Thornthwaite method), so the mean annual water deficit is around $1000 \mathrm{~mm}$. A natural shrubland dominated by Rosmarinus officinalis, Cistus albidus, Thymus hyemalis, Globularia alypum and Artemisia sp. ( $37^{\circ} 57^{\prime}$ $11^{\prime \prime} \mathrm{N}, 0^{\circ} 56^{\prime} 28^{\prime \prime} \mathrm{W} ; 155 \mathrm{~m}$ a.s.1.) located on the steep upper-slopes and adjacent to both cropping systems was used as a reference site to represent the pre-cultivated conditions.

Soils in the study area, developed on marl, are classified as Calcaric Eutric Regosols (IUSS Working Group WRB 2015). They have a silt-loam texture, a $\mathrm{pH}\left(\mathrm{H}_{2} \mathrm{O}, 1: 5\right)$ of 8.9 , a high $\mathrm{CaCO} 3$ content $(\sim 54 \%$ and $\sim 58 \%$ for rainfed and irrigated cropping systems, respectively), and an electrical conductivity of
0.20 and $1.37 \mathrm{dS} \mathrm{m}^{-1}$ for rainfed and irrigated croplands, respectively. The soil organic carbon (SOC) content in the study area is relatively low (4.5 and $8.2 \mathrm{~g} \mathrm{~kg}^{-1}$ in the rainfed and irrigated croplands, respectively), while the total nitrogen $(\mathrm{N})$ content is 0.7 and $1.3 \mathrm{~g} \mathrm{~kg}^{-1}$ in the rainfed and irrigated croplands, respectively (Table 1). The average slope of the rainfed and irrigated cropland is about $10 \%$ and $12 \%$, respectively. The shrubland (used as reference site) has a slope of about $20 \%$ and a soil organic carbon and nitrogen content of 11.7 and $1.4 \mathrm{~g} \mathrm{~kg}^{-1}$, respectively. In 1950, almond trees were planted in rows with a $7 \mathrm{~m} \times 7 \mathrm{~m}$ spacing in 1950 , since when no fertilizers have been applied. The mandarin trees were planted in 2000, at a spacing of $6 \mathrm{~m}$ between rows and $4 \mathrm{~m}$ between trees within the same row. In 2018, two crop diversification practices were implemented in the rainfed almond orchard. These consisted of intercropping a proportion of the rainfed almond trees with caper (Capparis spinosa) (Diversification 1 ; D1) at a spacing of $3.5 \mathrm{~m} \times 3.5 \mathrm{~m}$, or with thyme (Thymus hyemalis) (Diversification 2; D2) at a spacing of $1 \mathrm{~m} \times 0.5 \mathrm{~m}$, leaving the remaining part of the

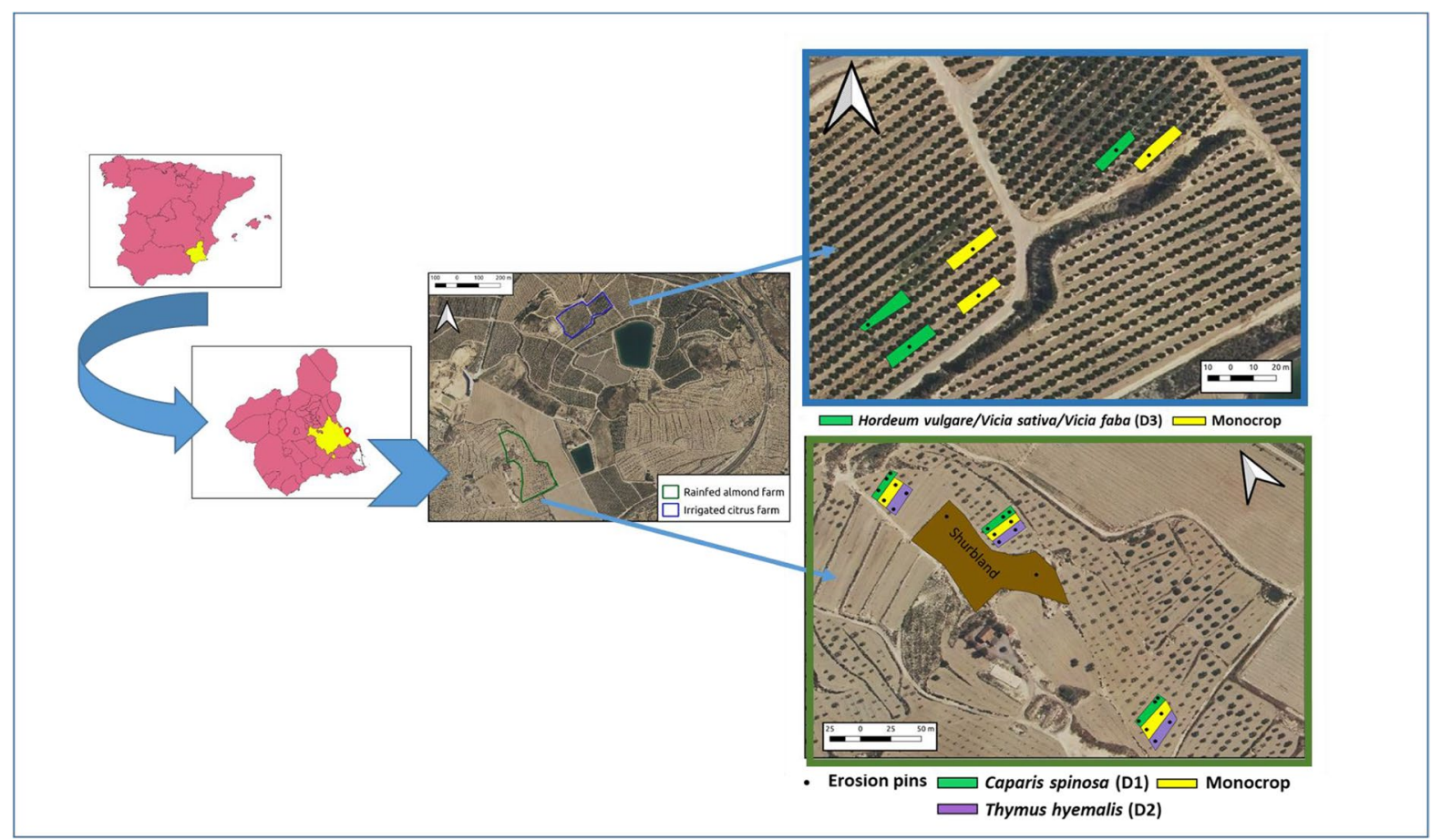

Fig. 1 Location of the study area and experimental design in the cropping systems under rainfed and irrigated conditions: blocks and treatments and locations of erosion pin plots 
Table 1 Physico-chemical properties of soils in the shrubland and in the monocrop and diversified cropping systems under rainfed and irrigated conditions. Means \pm standard deviations are shown

\begin{tabular}{|c|c|c|c|c|c|c|}
\hline \multirow[b]{3}{*}{ Soil Properties } & \multirow{3}{*}{ Shrubland } & \multicolumn{5}{|c|}{ Cropping system } \\
\hline & & \multirow[b]{2}{*}{ Monocrop } & \multicolumn{2}{|l|}{ Rainfed } & \multicolumn{2}{|l|}{ Irrigated } \\
\hline & & & D1 & D2 & Monocrop & D3 \\
\hline \multicolumn{7}{|l|}{ Texture } \\
\hline Clay & $22.5 \pm 1.1$ & & $26.5 \pm 4.2$ & & $13.6 \pm 2.3$ & \\
\hline Silt & $68.8 \pm 0.6$ & & $64.7 \pm 1.9$ & & $67.7 \pm 6.6$ & \\
\hline Sand & $8.8 \pm 1.4$ & & $8.8 \pm 3.0$ & & $18.3 \pm 7.9$ & \\
\hline $\mathrm{BD}\left(\mathrm{g} \mathrm{cm}^{-3}\right)$ & $1.4 \pm 0.06$ & $1.17 \pm 0.03 \mathrm{a}$ & $1.28 \pm 0.1 b$ & $1.27 \pm 0.08 b$ & $1.24 \pm 0.08$ & $1.16 \pm 0.13$ \\
\hline $\operatorname{SOC}\left(\mathrm{g} \mathrm{Kg}^{-1}\right)$ & $11.7 \pm 0.8$ & $4.52 \pm 0.5$ & $4.70 \pm 0.79$ & $3.8 \pm 0.78$ & $9.84 \pm 3.11$ & $8.17 \pm 1.52$ \\
\hline $\mathrm{TN}\left(\mathrm{g} \mathrm{Kg}^{-1}\right)$ & $1.4 \pm 0.07$ & $0.73 \pm 0.05$ & $0.69 \pm 0.12$ & $0.54 \pm 0.09$ & $1.29 \pm 0.25$ & $1.15 \pm 0.15$ \\
\hline $\mathrm{C}: \mathrm{N}$ & $8.5 \pm 1.0$ & $6.19 \pm 0.64$ & $6.23 \pm 0.88$ & $5.65 \pm 2.23$ & $8.12 \pm 0.92$ & $7.84 \pm 1.0$ \\
\hline OC Stock $\left(\mathrm{g} \mathrm{m}^{-2}\right)$ & $1638.2 \pm 20$ & $526.3 \pm 56.1$ & $578.5 \pm 121.9$ & $474.5 \pm 94.2$ & $1323.2 \pm 404.5 b$ & $1036.4 \pm 103.8 \mathrm{a}$ \\
\hline
\end{tabular}

D1: Diversification 1 (rainfed almond trees inter cropped with Capparis spinosa); D2: Diversification 2 (rainfed almond trees intercropped with Thymus hyemalis); D3: Diversification 3 (irrigated mandarin trees intercropped with crop rotations of Hordeum vulgare/Vicia sativa and Vicia faba). Different letters in rows mean significant differences between monocrop and diversification within each cropping system at $P<0.05$

almond crop as a monocrop. In the irrigated mandarin orchard, the diversification (Diversification 3; D3) consisted of intercropping with barley and vetch (Hordeum vulgare and Vicia sativa) (from February to June), followed by fava bean (Vicia faba) (from October to January), again leaving a proportion as a momocrop. Barley and vetch seeds (1:3 ratio) were manually sown at $150 \mathrm{~kg} \mathrm{ha}^{-1}$ covering the entire alley surface. Fava bean seeds were manually sown in three rows in each alley with a spacing of $100 \mathrm{~cm}$ between rows and $40 \mathrm{~cm}$ between plants $(2.5$ plants $\mathrm{m}^{-2}$ ). Crop residues, both from barely/vetch and fava bean were incorporated in the soil after harvest as green manure.

To compare the diversification systems with their respective monocrop systems a randomizedblock design with three replicate plots per treatment was established in both the rainfed and the irrigated orchards. Thus, nine plots $\left(200 \mathrm{~m}^{2}\right)$ in the rainfed almond orchard and 6 plots $\left(340 \mathrm{~m}^{2}\right)$ in the irrigated mandarin orchard were established (Fig. 1). In the rainfed monocrop plots, the whole plot area, including the area around the trunk base of each tree was chisel ploughed to $15 \mathrm{~cm}$ depth. Tillage was performed twice a year (in autumn and spring) to control weeds. In the diversified rainfed plots, an area of about $1 \mathrm{~m}$ around the trunk base of each tree (but not the alleys) was also tilled twice a year. In the irrigated orchard, the monocrop was tilled in November 2019 and January, March, September and October 2020 (chisel ploughing at $20 \mathrm{~cm}$ depth). Tillage in the diversified irrigated plots was performed just before sowing the crops in the alleys and after harvest to incorporate crop residues into the soil. A drip irrigation system was installed in all the tree rows, with one line per tree row and 3 pressure-compensated emitters $\left(4 \mathrm{~L} \mathrm{~h}^{-1}\right)$ per tree. The irrigation water applied to the mandarin monocrop during the experimental period was $6700 \mathrm{~m}^{3} \mathrm{ha}^{-1}$, while in the diversified plots the application rate was $4800 \mathrm{~m}^{3} \mathrm{ha}^{-1}$ for mandarin, 1200 $\mathrm{m}^{3} \mathrm{ha}^{-1}$ for fava bean and $700 \mathrm{~m}^{3} \mathrm{ha}^{-1}$ for barley/ vetch.

Fertilizers were applied by fertigation as a mixture of soluble $\mathrm{N}, \mathrm{P}, \mathrm{K}, \mathrm{Ca}, \mathrm{Mg}$ and related oligoelements. Table $\mathrm{S} 1$ shows the quantity of $\mathrm{N}, \mathrm{P}$ and $\mathrm{K}$ added with the fertilizers per treatment and crop each month. For more details on the irrigation management, see supplementary material.

Soil sampling and analysis

Soil samples were collected at $0-10 \mathrm{~cm}$ depth in April 2020, two years after the diversification practices started to be implemented. The soils were sampled in the alleys between the trees, $2 \mathrm{~m}$ from the tree trunks. Three disturbed composite soil samples (each 
one from five randomly collected subsamples) were taken per management practice and block in each cropping system for chemical analyses, including texture, total carbon and total nitrogen. In the natural shrubland, a total of five disturbed composite soil samples (0-10 cm depth) were randomly collected at different points. Undisturbed samples were also collected at the same spots using steel cylinders (100 $\mathrm{cm}^{3}$ core volume) for bulk density determinations.

The disturbed soil samples were air-dried and sieved to $<2 \mathrm{~mm}$. Soil texture was determined using a Coulter LS200 'Laser particle sizer' (Coulter Corporation, Miami, Florida). Previously, soil samples were treated with hydrogen peroxide to remove organic matter before being dispersed using sodium hexametaphosphate for $12 \mathrm{~h}$. Soil bulk density (BD, in $\mathrm{g} \mathrm{cm}^{-3}$ ) was calculated from the oven-dried mass $\left(105{ }^{\circ} \mathrm{C}, 24 \mathrm{~h}\right)$ following the method described by Burke et al. (1986). Bulk soil organic carbon (SOC, in $\mathrm{g} \mathrm{kg}^{-1}$ ) and total nitrogen (total $\mathrm{N}$, in $\mathrm{g} \mathrm{kg}^{-1}$ ) were analyzed using an N/C Analyzer (Flash 1112 EA, Thermo-153 Finnigan, Bremen, Germany) after elimination of the soil carbonates with $1 \mathrm{M} \mathrm{HCl}$.

\section{Soil organic carbon stocks}

The soil organic carbon stock at $0-10 \mathrm{~cm}$ depth (in $\mathrm{g} \mathrm{C} \mathrm{m}^{-2}$ ) was calculated as follows:

$S O C_{\text {stock }}=S O C \times B D \times D$

where $\mathrm{SOC}_{\text {stock }}$ is the accumulated carbon in the soil in $\mathrm{g} \mathrm{m}^{-2}$; SOC is the concentration of soil organic carbon in $\mathrm{g} \mathrm{kg}^{-1}$; $\mathrm{BD}$ is the soil bulk density in $\mathrm{g}$ $\mathrm{cm}^{-3}$; and $\mathrm{D}$ is the soil depth in $\mathrm{cm}$.

Soil $\mathrm{CO}_{2}$ emissions, temperature and volumetric soil water content

Soil $\mathrm{CO}_{2}$ emission rates to the atmosphere were measured in situ every 7-20 days, depending on climate conditions and equipment availability in all the replicated treatments from April 2019 to October 2020, and always between 9:00 and 13:00. The basic experimental procedure used in this study was the dynamic gas chamber technique (Álvaro-Fuentes et al. 2019; López-Teloxa and Monterroso-Rivas 2020; Wolff et al. 2018). The chambers were inserted into the bare soil to a depth of $10 \mathrm{~cm}$, in the middle of the alleys between two tree rows, $3 \mathrm{~m}$ from the tree trunks in both almond and mandarin monocrops. In the almond plots diversified with thyme or caper, chambers were inserted within four thyme or caper plants, equidistant to all plants in all cases ( 0.40 or $1.5 \mathrm{~m}$ for thyme and caper, respectively), and between two trees. In the diversified mandarin plots, chambers were randomly inserted between two fava bean plants in the central row (15-20 cm to each of them). The chambers were inserted in the middle of the alleys in the periods when no intercrops grew in the mandarin alleys and when barley/vetch was present. The area inside the chambers were kept free of vegetation throughout the experimental time to measure soil emissions only. Simultaneously with the soil $\mathrm{CO}_{2}$ efflux measurements, the soil temperature and volumetric water content were measured at $0-10 \mathrm{~cm}$ depth close to each soil chamber using a ProCheck and 5TM sensors (Decagon Devices, USA).

By assuming that midday measurements are reasonable estimates of the mean daily emission rates (Davidson et al. 1998; $\mathrm{Xu}$ and Qi 2001), the $\mathrm{CO}_{2}$ emission rates conducted within the same month were first averaged to provide the daily mean soil $\mathrm{CO}_{2}$ emission rates for each month. Daily soil $\mathrm{CO}_{2}$ emission rates for each month of the year were then multiplied by the number of days in the month to calculate mean soil $\mathrm{CO}_{2}$ emission rates for each month. The amount of carbon released to the atmosphere from the soil annually for each management treatment and study site was computed as the sum of the monthly rates as described by other authors (McCulley et al. 2004).

Soil detached/deposited and associated mobilized carbon

Soil erosion rates were measured using erosion pin plots $(1 \mathrm{~m} \times 1 \mathrm{~m})$, each consisting of three lines of three pins with a distance of $0.5 \mathrm{~m}$ between them. Erosion pin plots were randomly distributed in the different land-uses and diversification treatments. In the rainfed cropping system, two or three erosion pin plots per block ( $\mathrm{n}=9$ or 6 ) were set up in the two diversifications and in the control treatment (monocrop). In the irrigated cropping system, six erosion pin plots (one per block) were set up in the alleys between rows in the diversification and in the control treatment (monocrop). In the shrubland, two 
erosion pin plots were set up to estimate erosion rates occurring under natural conditions (Fig. 1). Pins were measured monthly and after each rainfall event from April 2019 to October $2020 \quad(n=17)$, identifying detachment and deposition patterns occurring during the erosion process, based on the average difference in the height of each pin after an erosive event compared with the previously measured differences. That is, negative values indicate the predominance of deposition of eroded sediments while positive values indicate the predominance of detachment (Hancock and Lowry 2015). Rainfall characteristics of the different events occurring during the study period were obtained from our own meteorological station located $1 \mathrm{~km}$ from the experimental area (Table 2).

In the rainfed and irrigated cropping systems, the sediments deposited in sink areas at the bottom of the erosion pin plots after each erosive event were collected for organic carbon determinations. Sediment samples were oven-dried at $60{ }^{\circ} \mathrm{C}$, ground and analysed to determine the organic $\mathrm{C}$ content using the same procedure as fused or the soil samples. After each erosive event, the organic carbon concentration in sediments was multiplied by the net erosion rate (i.e., the difference between detached and deposited

Table 2 Date of erosion pins measurements and total accumulated rainfall and maximum rainfall intensity in thirty minutes $\left(\mathrm{I}_{30}\right)$ in the study period

\begin{tabular}{lll}
\hline Pins measured Date & $\begin{array}{l}\text { Accumulated rain- } \\
\text { fall }(\mathrm{mm})\end{array}$ & $\mathrm{I}_{30}\left(\mathrm{mmh}^{-1}\right)$ \\
\hline $17 / 04 / 2019$ & 31 & 9.2 \\
$29 / 04 / 2019$ & 152 & 14.8 \\
$05 / 06 / 2019$ & 0.0 & 0.0 \\
$24 / 07 / 2019$ & 0.0 & 0.0 \\
$02 / 09 / 2019$ & 75.8 & 19.2 \\
$20 / 09 / 2019$ & 321.2 & 130.4 \\
$27 / 09 / 2019$ & 22.6 & 3.6 \\
$13 / 12 / 2019$ & 65.6 & 10 \\
$29 / 01 / 2020$ & 80 & 13.2 \\
$25 / 02 / 2020$ & 3.8 & 0.64 \\
$13 / 04 / 2020$ & 131.4 & 6.4 \\
$28 / 04 / 2020$ & 42 & 28.8 \\
$28 / 05 / 2020$ & 31 & 14.4 \\
$16 / 06 / 2020$ & 7.4 & 4 \\
$29 / 07 / 2020$ & 2.6 & 4 \\
$03 / 09 / 2020$ & 7.6 & 5.6 \\
$24 / 09 / 2020$ & 3.6 & 5.6 \\
\hline
\end{tabular}

sediment). To estimate the OC concentration of sediments in the shrubland, where no data were available, we assumed the same enrichment ratios (i.e., OC in sediments relative to the OC in soils) as previously observed in nearby sites under the same environmental conditions $(\mathrm{ERoc}=2.23$, Martínez-Mena et al. 2008). The enrichment OC ratios measured at the cultivated areas were $1.35,1.54$ and 0.97 for rainfed monocrop, D1 and D2, respectively; and 0.77 and 1.05 for the irrigated monocrop and D3, respectively. Total OC outputs or inputs by erosion for each diversified and monoculture practice were calculated as the sum of the net OC detached or deposited after every erosion event over a period of 18 months.

\section{Carbon inputs from vegetation}

Annual plant carbon inputs from the alleys between rows were estimated using a combination of methods tailored for the different diversified and monoculture systems and the natural shrubland.

Total plant biomass in each cropping system and management practice included, if present, spontaneous plant species growing in the plot together with the diversified crop. In the rainfed systems, above-ground biomass from the spontaneous vegetation and intercrop was collected from three quadrats $(1 \mathrm{~m} \times 1 \mathrm{~m})$ randomly placed for each management treatment and block. The plant material was dried at $60{ }^{\circ} \mathrm{C}$ for $72 \mathrm{~h}$, and weighed. To estimate the below-ground biomass of the spontaneous vegetation we assumed a shoot:root ratio of 0.23 , as previously estimated in a nearby non-tilled rainfed almond orchard (Almagro et al. 2017). Above-ground biomass inputs from Capparis spinosa (D1) and Thymus hyemalis (D2), were estimated by assuming that $25 \%$ of the total harvested aboveground-biomass is returned to the soil as litterfall, as reported in previous studies conducted under semiarid conditions (Abanda et al. 2011; Perez-Quezada et al. 2011). In the irrigated cropping system, sequential harvesting of above- and below-ground biomass was performed at the biomass peak of each crop used for the rotation. All the barley and vetch plants were collected in June 2019 and 2020 from three quadrats $(1 \mathrm{~m} \times 1 \mathrm{~m})$ randomly placed in each block. Roots and shoots were carefully separated and dried in an oven at $70^{\circ} \mathrm{C}$ until stable weight to estimate root and shoot biomass. Only root biomass was considered as a carbon input to the system since the 
above-ground biomass was harvested and used for feeding livestock at a nearby site. The total fava bean biomass was estimated by collecting three individual plants after harvesting in December 2019 and 2020.

In the shrubland, carbon inputs from vegetation were assumed to be the same of those observed in a nearby shrubland with similar plant cover percentage and species composition (Rosmarinus officinalis and Thymus sp.; Almagro et al. 2010).

Annual plant carbon inputs were estimated as the total biomass production for each diversified and monoculture system multiplied by 0.48 as the average carbon content of plant material (Almagro et al. 2010). Average annual plant carbon inputs for the period April 2019 to October 2020 are reported in Table 3.

Conceptual framework and description of the soil carbon balance approach

Before implementation of the diversification practices, a steady-state equilibrium can be assumed with regard to the SOC level since both the rainfed and irrigated agricultural fields had been under the same management for at least 20 years (Burke et al. 1995; Lal 2008). Our second assumption is that SOC sequestration in the alleys between rows of these agricultural fields would begin after the different crop diversification practices had begun and would continue until pre-cultivation SOC levels (i.e., those of the adjacent shrubland) were reached, according to its attainable SOC sink capacity. To assess the effect of diversified $v s$. monoculture practices on the annual SOC accumulation rate of the rainfed and irrigated woody cropping systems, we adapted the conservation mass approach proposed by Yoo et al. (2005), whereby any change in the $\mathrm{C}$ stored in the soil per unit of time (t) is given by the difference between $\mathrm{C}$ inputs (plant $\mathrm{C}$ inputs and depositional $\mathrm{SOC}$ inputs) and losses from the soil $\left(\mathrm{CO}_{2}\right.$ released to the atmosphere and erosional loss of SOC):

$\frac{d S O C}{d t}=N P P-R s-\varepsilon$

where SOC is soil organic carbon storage (in $\mathrm{g} \mathrm{C}$ $\mathrm{m}^{-2}$ ), $\mathrm{t}$ is time (year), NPP is the annual carbon input from the spontaneous vegetation and the diversified crops $\left(\mathrm{g} \mathrm{C} \mathrm{m}^{-2} \mathrm{yr}^{-1}\right)$, Rs is the annual amount of carbon released to the atmosphere through soil respiration $\left(\mathrm{g} \mathrm{C} \mathrm{m}^{-2} \mathrm{yr}^{-1}\right)$ and $\varepsilon$ is the carbon exported or deposited as a result of water erosion $\left(\mathrm{g} \mathrm{C} \mathrm{m}^{-2} \mathrm{yr}^{-1}\right)$.

Biomass carbon inputs from the main crops (i.e., almond and mandarin tress) were not considered in the soil carbon balance approach, which focused on the alley between rows. In this sense, previous research has highlighted the important role of the

Table 3 Soil carbon fluxes (outputs and inputs) and balance (in $\mathrm{g} \mathrm{C} \mathrm{m}^{-2} \mathrm{y}^{-1}$ ) in the shrubland (as reference site) and in the monocrop and diversified cropping systems under rainfed and irrigated conditions.

\begin{tabular}{|c|c|c|c|c|c|c|}
\hline & \multirow{3}{*}{ Shrubland } & \multicolumn{5}{|l|}{ Cropping system } \\
\hline & & \multicolumn{3}{|l|}{ Rainfed } & \multicolumn{2}{|l|}{ Irrigated } \\
\hline & & Monocrop & D1 & D2 & Monocrop & D3 \\
\hline $\begin{array}{l}\mathrm{C} \text { released to the } \\
\text { atmosphere by soil } \\
\text { respiration }\end{array}$ & $305 \pm 54.4$ & $233.6 \pm 25.9 b$ & $174.8 \pm 17.6 \mathrm{a}$ & $184.4 \pm 15.4 a$ & $382.9 \pm 42.84$ & $478.3 \pm 40.9$ \\
\hline Plant $\mathrm{C}$ inputs & $193.75 \pm 14.2$ & $60.8 \pm 12.6 \mathrm{a}$ & $125.37 \pm 8.9 b$ & $142.52 \pm 11.8 b$ & $\mathrm{n}$ & $70.48 \pm 7.1$ \\
\hline $\begin{array}{l}\mathrm{C} \text { exported/accumu- } \\
\text { lated by erosion } \\
\text { processes }\end{array}$ & $-59.47 \pm 4.1$ & $34.4 \pm 7.3 b$ & $23.35 \pm 11.3 \mathrm{a}$ & $13.18 \pm 7.6 \mathrm{a}$ & $15.41 \pm 6.9$ & $9.95 \pm 4.2$ \\
\hline Soil carbon balance & $-51.77 \pm 72.7$ & $7-207.16 \pm 45.8$ & $-72.78 \pm 36.8$ & $-55.12 \pm 34.8$ & $-398.33 \pm 49.7$ & $-414.27 \pm 52.2$ \\
\hline
\end{tabular}

Average \pm standard errors are shown. Negative values of $\mathrm{C}$ exported/accumulated by erosion processes correspond to deposition of sediments

D1: Diversification 1 (rainfed almond trees intercropped with Capparis Spinosa); D2: Diversification 2 (rainfed almond trees intercropped with Thymus hyemalis); D3: Diversification 3 (irrigated mandarin trees intercropped with crop rotations of Hordeum vulgare/Vicia sativa and Vicia faba). n: negligible. Different letters in rows mean significant differences between monocrop and diversification within each farming system at $P<0.05$ 
alley between rows in the soil $\mathrm{C}$ budget of woody cropping systems with wide row spacing, as in our study sites (Midwood et al. 2020; Tezza et al. 2019).

Since no soil $\mathrm{CO}_{2}$ efflux measurements were performed in the native shrubland (as the reference site) averaged annual soil $\mathrm{CO}_{2}$ emission rates for this site were assumed to be comparable to the average annual $\mathrm{CO}_{2}$ emission rates of seven native Mediterranean shrublands under similar climatic conditions (mean annual precipitation less than $400 \mathrm{~mm}$ ) included in the global soil respiration database by Bond-Lamberty and Thomson (2012).

\section{Statistical analyses}

Differences in soil properties, and SOC and $\mathrm{CO}_{2}$ emissions between diversified and monocrop systems were analysed using a General Linear Model (GLM) procedure, in which treatment was considered as a fixed factor and block as a random variable. When significant differences among treatments were identified at the 0.05 probability level of significance, the mean values were compared using Tukey's test. The data were previously examined for normality by the Kolmogorov-Smirnov test and for homogeneity of variances by Levene's test. Differences in erosion rates between the monocrops and diversified crops were analysed separately for each rainfed and irrigated cropping system using a non-parametric Kruskal-Wallis test because of the lack of normality of this variable.

\section{Results}

\section{Soil properties}

Under rainfed conditions, soil bulk density significantly increased in the diversified systems compared to the monocrop, but no significant differences in soil organic carbon and nitrogen contents or SOC stocks were detected among them. Under irrigated conditions, there were no significant differences in soil bulk density, OC or total $\mathrm{N}$ content between the diversified and the monocrop cropping systems, although OC stocks were lower in the diversified system.

The shrubland (reference site) showed higher soil organic carbon and nitrogen contents and stocks than the irrigated and rainfed cropping systems (Table 1).
Mean temperature, volumetric water content and soil $\mathrm{CO} 2$ emissions

Mean soil temperatures were $24.30 \pm 0.87{ }^{\circ} \mathrm{C}$ and $25.34 \pm 1.12{ }^{\circ} \mathrm{C}$ for the rainfed and the irrigated monocrop cropping systems, respectively, during the study period (Fig. 2a) and did not differ between the diversified and monoculture practices under rainfed or irrigated conditions. Mean soil volumetric water content was $0.10 \pm 0.01 \mathrm{~m}^{3} \mathrm{~m}^{-3}$ and $0.12 \pm 0.01$ $\mathrm{m}^{3} \mathrm{~m}^{-3}$ for the rainfed and the irrigated cropping system, respectively (Fig. 2b). Under rainfed conditions, the soil water content was similar between diversified crop and monocrop systems. However, under irrigated conditions, the soil water content was significantly higher (by about 25\%) in the crop diversification treatment than in the monocrop.

Mean soil $\mathrm{CO}_{2}$ emission rates were $96.69 \pm 10.9$ and $160.3 \pm 17.9 \mathrm{mg} \mathrm{CO}_{2} \mathrm{~m}^{-2} \mathrm{~h}^{-1}$ in the rainfed and irrigated monocrop cropping systems, respectively (Fig. 2c). Contrasting effects of crop diversification on soil $\mathrm{CO}_{2}$ emission rates were observed in the rainfed and irrigated cropping systems. Soil $\mathrm{CO}_{2}$ emission rates were significantly reduced by $23 \%$, on average in both crop diversification treatments compared with the monocrop system under rainfed conditions. However, under irrigated conditions, soil $\mathrm{CO}_{2}$ emission rates were $25 \%$ higher with crop diversification (Fig. 2c).

Soil detached/deposited and carbon associated with the sediments

During the study period (from 19th March 2019 to 2nd October 2020), 55 rainfall events (>1 mm) produced a total rainfall of $948.4 \mathrm{~mm}$, of which 16 events produced soil water erosion in the experimental area. Mean maximum rainfall intensity in $30 \mathrm{~min}\left(\mathrm{I}_{30}\right)$ during the study period was $5.96 \mathrm{~mm} \mathrm{~h}^{-1}$ in both cropping systems. The total rainfall was higher than the annual average $(230 \mathrm{~mm})$ given for this area due to the occurrence of three extreme events during the study period. The highest-intensity rainfall event (maximum $\mathrm{I}_{30}$ of $130 \mathrm{~mm} \mathrm{~h}^{-1}$ ) occurred in September 2019, during which a total of $321 \mathrm{~mm}$ accumulated in two consecutive days. April 2019 and 2020 produced an accumulation of 152 and $131 \mathrm{~mm}$, respectively, and displayed a maximum $\mathrm{I}_{30}$ of $14.8 \mathrm{~mm} \mathrm{~h}^{-1}$ (Table 2). 
Fig. 2 Mean soil temperature (a), volumetric soil water content $(\mathbf{b})$ and $\mathrm{CO}_{2}$ emission rates $(\mathbf{c})$ in the monocrop and diversified cropping systems under rainfed and irrigated conditions. Means and standard errors are shown. D1: Diversification 1 (rainfed almond trees intercropped with Capparis spinosa); D2: Diversification 2 (rainfed almond trees intercropped with Thymus hyemalis); D3: Diversification 3 (irrigated mandarin trees intercropped with crop rotations of Hordeum vulgare/Vicia sativa and Vicia faba). Within each farming system, different lower cases indicate significant differences between the diversifications and the monocrop (control) systems at $p<0.05$
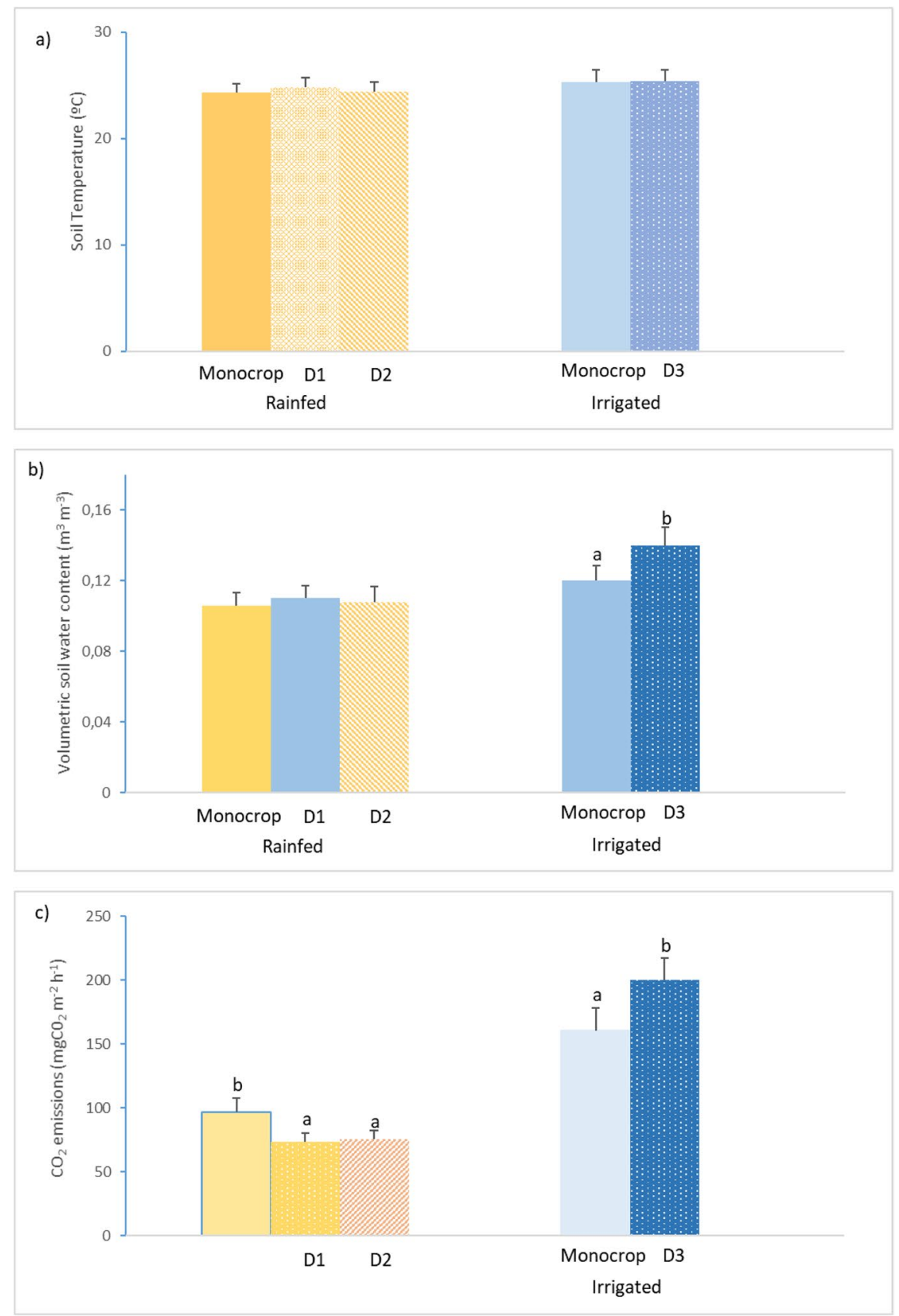

According to the erosion pin measurements, detachment and deposition phases were observed in the different crop diversifications and monocrop systems during the study period. Both cropping systems generally showed higher detachment losses than deposition gains, leading to soil loss. In the shrubland, however, deposition gains were higher than detachment losses, meaning that the deposition phase prevailed throughout the study period. At the end of the study period, total soil loss in the monocrop and crop diversification systems ranged from 84.5 to $54.5 \mathrm{t}$ soil ha ${ }^{-1}$ (under rainfed conditions) and from 30.4 to $17.3 \mathrm{t}$ soil $\mathrm{ha}^{-1}$ (under irrigated conditions), respectively, while $34.3 \mathrm{t}_{\text {soil ha }}{ }^{-1}$ were deposited in the shrubland (Fig. 3). 
Fig. 3 Average and standard error of the net erosion rates in the shrubland (a), rainfed (b) and irrigated (c) cropping systems, with distinction between the detachment and the deposition (negative values indicate deposition of eroded material) processes. Diversification 1 (intercropping with Capparis spinosa); D2: Diversification 2 (intercropping with Thymus hyemalis); D3: Diversification 3 (crop rotation of Hordeum vulgare and Vicia satival Vicia faba). Different lower cases indicate significant differences within each farming system between the diversifications and the monocrop (control) systems at $p<0.05$
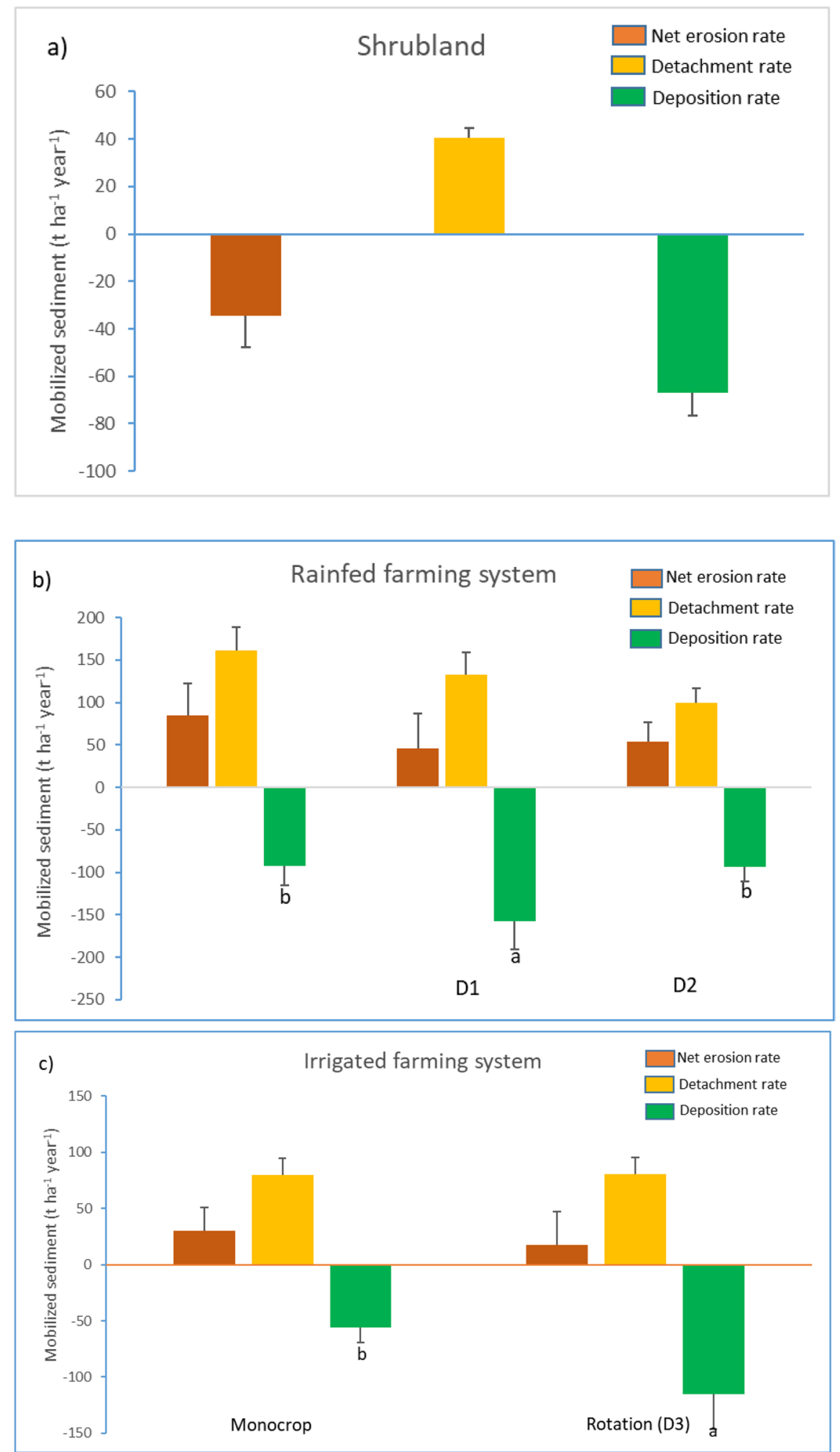
Overall, the diversifications adopted in the formerly monocrop rainfed and irrigated systems showed higher deposition rates but slightly lower soil detachment rates (Fig. 3b and c). As a result, the total net erosion rate (detachment rate minus deposition rate) was reduced by $36-45 \%$ as a result of diversifications in the rainfed cropping system, and by $43 \%$ after diversification of the irrigated cropping system.

The average carbon content in sediments was $6.1 \pm 1.2 \mathrm{~g} \mathrm{~kg}^{-1}, \quad 7.6 \pm 2.6 \mathrm{~g} \mathrm{~kg}^{-1}$ and $26.0 \pm 1.85 \mathrm{~g} \mathrm{~kg}^{-1}$ in the rainfed monocrop, irrigated monocrop and shrubland, respectively. As expected, higher carbon losses through erosion were observed in the monocrop compared to the diversified cropping systems under both rainfed and irrigated conditions (Table 3). Diversification with caper and thyme reduced the organic carbon mobilized by erosion by 32 and $61 \%$, respectively, compared to the monocrop system under rainfed conditions (Table 3). Likewise, the diversification system reduced losses of carbon through erosion by $35 \%$ compared to the monocrop system under irrigated conditions. The native shrubland, by contrast, gained around $60 \mathrm{~g} \mathrm{C} \mathrm{m}^{-2} \mathrm{yr}^{-1}$ from the deposited sediments, acting as an erosion carbon sink.

Organic carbon inputs derived from vegetation

Intercropping increased total (above- and belowground) biomass and, hence, the plant $\mathrm{C}$ inputs returned to the soil in the alley between rows, in both rainfed and irrigated cropping systems compared to their respective monocrop systems (Table 3). More specifically, under rainfed conditions, plant $\mathrm{C}$ inputs doubled in the plots diversified with caper and thyme compared with the monocrop system. In irrigated conditions, intercropping increased the plant $\mathrm{C}$ inputs compared to the monocrop system, considering that $\mathrm{C}$ inputs were negligible in the irrigated crop (Table 3).

\section{Soil organic carbon balance approach}

Based on the findings of our soil carbon balance approach, all the systems acted as carbon source. The annual carbon balance (inputs-outputs) was -51 , -207 and $-413 \mathrm{~g} \mathrm{C} \mathrm{m}^{-2} \mathrm{y}^{-1}$ for the shrubland, rainfed and irrigated monocrop cropping systems, respectively (Table 3). Intercropping the rainfed almond crops with caper or thyme enhanced plant carbon inputs, while reducing carbon losses through erosion and respiration. Therefore, the net soil carbon balance improved significantly (by $65 \%$ and $73 \%$ in D1 and D2, respectively) compared with the monocrop system. By contrast, intercropping with a rotation of a mixture of barley and vetch, followed by fava bean, in the irrigated mandarin crop did not improve the net soil carbon balance, and even produced slightly higher carbon losses (Table 3). In this case, the observed increase in the carbon inputs from the established vegetation, together with the decrease in carbon losses through erosion, was not off-set by the greater carbon losses through increased soil respiration.

\section{Discussion}

Impact of crop diversification on soil carbon stocks

In our study site, crop diversification practices did not enhance SOC stocks in the rainfed or in irrigated cropping system. This may be explained by the shortterm duration of this study (i.e., 18 months) together with the extreme environmental conditions (low rainfall, high evapotranspiration) low organic matter content of the soil $(<1 \%)$ and highly erodible marly substrate of the study site), which hampered the new crop establishment and slowed down soil organic carbon dynamics and sequestration (Ogle et al. 2005). Although crop diversification was seen to enhance plant carbon inputs in the alley between rows of both cropping systems (Table 3), a longer time is still needed for these plant residues to be decomposed and incorporated into the soil as a stable soil organic matter pool. It is also important to consider the recalcitrant nature of the plant residues derived from the intercropped perennial species (thyme and caper) in the rainfed diversified systems (Almagro et al. 2021).

Impacts of crop diversification on soil $\mathrm{CO}_{2}$ emissions

Crop diversification significantly increased annual soil $\mathrm{CO}_{2}$ emissions by $25 \%$ in the irrigated cropping system while the opposite occurred in the rainfed cropping system. This contrasting pattern can be explained by the different crop diversification strategies (i.e., intercropping with annual vs. perennial crops) and soil management practices adopted in both 
cropping systems. The higher soil $\mathrm{CO}_{2}$ emissions in the diversified compared than in the monocrop system under irrigated conditions may be explained by several factors. First, intercropping with annual crop rotations avoids bare soil in the alley between rows throughout the year, preventing soil water evaporation losses and improving the soil water balance, which ultimately drives higher soil $\mathrm{CO}_{2}$ emissions. Moreover, the inclusion of different cereal and leguminous species in the rotation scheme, together with irrigation and the addition of nutrients (mostly N, P and $\mathrm{K}$; Table S1) with fertilizers enhance root activity, rhizodeposition and soil microbial decomposition of new labile organic matter sources (the so-called "priming effect"; Kuzyakov 2002). Finally, tillage operations were performed four times per year, breaking up aggregates and accelerating organic matter decomposition.

By contrast, the reductions in the annual soil $\mathrm{CO}_{2}$ emission rates observed in both diversified crops under rainfed conditions could be explained by increased soil compaction (due to the absence of tilling inthese treatments), as indicated by the significant increase in soil bulk density values compared to the monoculture system (Table 1). According to several authors, as soil compaction increases, diffusive resistance to gas movement also increases (Gaertig et al. 2002; Hashimoto and Suzuki 2002; Pengthamkeerati et al. 2006). This observation is supported by the fact that no other major factors that control $\mathrm{CO}_{2}$ emissions from soils (such as soil temperature or moisture content) changed with crop diversification in the rainfed cropping system. Moreover, the plant material from the crops used for intercropping is more recalcitrant and $\mathrm{N}$-poor than that of the annual crops used in the rotation scheme of the irrigated cropping system (Almagro et al. 2021), which might also contribute to explaining the lower $\mathrm{CO}_{2}$ emissions in the diversified rainfed system.

Impacts of crop diversification on erosion and associated OC dynamics

The estimated net soil erosion rates (ranging from -34 to $84 \mathrm{t}$ soil $\mathrm{ha}^{-1} \mathrm{y}^{-1}$ ) were within the range of those reported in other studies conducted at hillslope scale in similar Mediterranean environments (García-Ruiz 2010; Taguas et al. 2015; Yoo et al. 2005). While net erosion rates were positive (indicating the prevalence of the detachment phase throughout the study period) in the cropping systems, the deposition phase was predominant in the reference shrubland site (Table 3 and Fig. 3), indicating that native vegetation acted as a barrier, retaining the sediment.

Crop diversifications reduced soil losses through erosion, and the associated carbon losses, by between 30 and $60 \%$, depending on crop diversification practices and cropping system (Fig. 3b, c).

Under irrigated conditions, intercropping reduced the amount of carbon losses through erosion by $35 \%$ compared with the monocrop system despite the depletion of organic carbon in sediments (enrichment ratios $<1$ ) observed in the latter. This result reinforces the idea that OC losses are mainly driven by the total soil lost by erosion rather than by the OC content of sediments, as reported in other studies (Owens et al. 2002).

Under rainfed conditions, intercropping with thyme (D2) was doubly more effective than intercropping with caper (D1) in reducing the amount of carbon lost by erosion. This is in line with the lower organic carbon enrichment ratio observed for the sediments resulting from the thyme-diversification (0.96) than that coming from the caper-diversification treatment (1.6), which might be related to the greater physical protection of organic carbon (Almagro et al. 2017; García-Franco et al. 2015) and/or to the size of material transported through erosion (Ordoñez-Fernández et al. 2007) with thyme as a diversification crop.

Besides reducing the $\mathrm{OC}$ exported from a given system through erosion (prevalent detachment phase), crop diversification can increase carbon inputs into the system by trapping sediments rich in OC, which will remain or be temporarily accumulated within the agricultural plot. The extent to which this carbon remains in the system will depend on many environmental factors, such as the topography of the cropland and of the surrounding area, the frequency and intensity of rainfall events, and the time elapsing from the introduction of diversification (i.e., the longer that diversification has been practised, the more the soil surface will be covered and protected against soil erosion, and thus the more $\mathrm{C}$ that will be retained in the system). 
Impacts of crop diversification on the soil carbon balance

Diversification practices under rainfed conditions improved the soil carbon balance (by reducing the carbon outputs by between 65 and $73 \%$, depending on the diversification crop only eighteen months following its implementation. Our results highlight the potential of intercropping with perennials in rainfed woody crop systems for achieving carbon neutrality, particularly in the longer-term, once the new crop is fully developed and the diversified system reaches a steady state (Smith et al. 2014). By contrast, under irrigated conditions, crop diversification did not improve the soil carbon balance. The higher annual soil $\mathrm{CO}_{2}$ emissions in the irrigated diversification treatment with respect to the monocrop system were not offset by the observed increase in plant carbon inputs and the reduction in carbon outputs by erosion. These results might suggest that, under intensively managed cropping systems, it is more difficult to improve the soil $\mathrm{C}$ balances to achieve carbon neutrality. These results are in line with those of other authors who found that intensively managed irrigated systems act as GHG sources, while low-input rainfed ones usually act as neutral carbon systems (Aguilera et al. 2015).

Based on our soil carbon balance approach, all the systems acted as carbon source, but agriculture intensification promoted higher carbon outputs from ecosystems to the atmosphere. Unfortunately, the lack of literature reporting soil carbon balances in Mediterranean agroecosystems under similar environmental and management conditions makes comparisons difficult. Noteworthy, other studies carried out in Mediterranean woody crop systems under rainfed and irrigated conditions using different approaches to estimate the carbon balance at the whole agroecosystem level reported much higher net carbon inputs and, as a result, those agroecosystems acted as $\mathrm{C}$ sinks (Brilli et al. 2016; Nardino et al. 2013; Palese et al. 2013).

Contribution of the different $\mathrm{C}$ fluxes to the soil carbon balance

Soil respiration was the major component of the soil carbon balance, followed by annual plant $\mathrm{C}$ inputs (NPP) and erosion in all three study sites (Table 3), which is in line with the results reported by other authors (Giardina and Ryan 2002). In both diversified systems under rainfed conditions and in the shrubland, carbon outputs through soil respiration were of the same order of magnitude as carbon inputs from vegetation. Moreover, in the shrubland, a significant proportion of the carbon mobilized by erosion was deposited within the system, contributing to the increase in the total carbon input of $24 \%$. Although carbon inputs and outputs in different ecosystems can vary annually depending on climatic conditions and vegetation development (Chamizo et al. 2017; Tezza et al. 2019), our results show the significant role played by soil erosion in controlling the net soil carbon balance of those systems, keeping them much closer to carbon neutrality. Likewise, our findings highlight the importance of considering the erosion process when estimating the soil carbon balance in Mediterranean ecosystems, in contrast to several reports suggesting the relatively small influence on the total soil carbon budget of carbon export due to erosion (Forrester et al. 2006; Giardina and Ryan 2002; Schlesinger 1986).

Under irrigated conditions, however, carbon outputs through respiration were one order of magnitude higher than carbon inputs due to crop diversification. This highlights the fact that, under highly intensive cropping systems, it is more difficult to improve soil $\mathrm{C}$ balances to achieve carbon neutrality. This is particularly true when crop material is harvested and taken out of the system as food or feed, as in the case of our study. Our results underline the importance of retaining crop residues for improving SOC balances.

Nevertheless, we cannot ignore the fact that the dissolution of carbonates would contribute to the amount of $\mathrm{CO}_{2}$ emitted from soils and that such contributions are dependent on many environmental and management factors (Cardinel et al. 2020). This is one drawback of the present study, and future research should include isotopic analyses $\left(\delta^{13} \mathrm{C}\right)$ to assess the contribution of inorganic carbon to the total $\mathrm{CO}_{2}$ emitted.

\section{Conclusions}

Crop diversification did not affect SOC stocks in our study, but did affect the carbon inputs and outputs regulating the short-term soil carbon balance in these Mediterranean agroecosystems. Crop diversification 
with perennials in the low-input rainfed woody crop system significantly improved the annual soil $\mathrm{C}$ balance in the short-term. Reductions of $23 \%$ in $\mathrm{CO}_{2}$ emissions and of about $45 \%$ in lateral $\mathrm{C}$ fluxes as a result of erosion, together with a significant increase in the OC inputs, contributed to enhancing the soil carbon balance of the diversified systems. Crop diversification using annual species in the intensively managed woody crop system did not improve the annual soil $\mathrm{C}$ balance but, a significant increase in plant carbon inputs and a reduction in the lateral carbon fluxes caused by erosion (53\%) was observed.

Our results highlight the potential of intercropping with perennials in rainfed woody crop systems for mitigating the effects of climate change through soil carbon sequestration. Indeed, the effects of such crop diversification on the carbon balance would be expected to be more pronounced in the long-term, once the new crops have fully developed and the diversified system reaches a steady state. Further research is needed if we are to confirm whether or not intercropping with perennials in irrigated cropping systems could be considered a solution to improving the soil carbon balance in these systems.

Acknowledgements This work was supported by the European Commission Horizon 2020 project Diverfarming [grant agreement 728003]. Raúl Zornoza acknowledges the financial support from the Spanish Ministry of Science, Innovation and Universities through the "Ramón y Cajal" Program [RYC-2015-18758].

Funding Open Access funding provided thanks to the CRUE-CSIC agreement with Springer Nature. This work was funding by the European Commission Horizon 2020 project Diverfarming (grant agreement 728003).

\section{Declarations}

Conflict of interest The authors declare that they have no known competing financial interests or personal relationships that could have appeared to influence the work reported in this paper.

Open Access This article is licensed under a Creative Commons Attribution 4.0 International License, which permits use, sharing, adaptation, distribution and reproduction in any medium or format, as long as you give appropriate credit to the original author(s) and the source, provide a link to the Creative Commons licence, and indicate if changes were made. The images or other third party material in this article are included in the article's Creative Commons licence, unless indicated otherwise in a credit line to the material. If material is not included in the article's Creative Commons licence and your intended use is not permitted by statutory regulation or exceeds the permitted use, you will need to obtain permission directly from the copyright holder. To view a copy of this licence, visit http://creativecommons.org/licenses/by/4.0/.

\section{References}

Abanda PA, Compton JS, Hannigan RE (2011) Soil nutrient content, above-ground biomass and litter in a semi-arid shrubland, South Africa. Geoderma 164:128-137. https:// doi.org/10.1016/j.geoderma.2011.05.015

Abbas F, Hammad HM, Fahad S, Ishaq W, Farooque AI, Bakhat HF, Zia Z, Fahad S, Farhad W, Cerdá A (2020) A review of soil carbon dynamics resulting from agricultural practices. Agric Ecosyst Environ 268:110319

Aguilera E, Lassaletta L, Gattinger A, Gimenoe BG (2013) Managing soil carbon for climate change mitigation and adaptation in Mediterranean cropping systems: a metaanalysis. Agric Ecosyst Environ 168:25-36. https://doi. org/10.1016/j.agee.2013.02.003

Aguilera E, Guzmán G, Alonso A (2015) Greenhouse gas emissions from conventional and organic cropping systems in Spain II. Fruit Tree Orchards Agron Sustain Dev 35:725-737. https://doi.org/10.1007/s13593-014-0265-y

Almagro M, López J, Boix-Fayos C, Albaladejo J, MartínezMena M (2010) Belowground carbon allocation patterns in a dry Mediterranean ecosystem: a comparison of two models. Soil Biol Biochem 42:1549-1557. https://doi.org/ 10.1016/j.soilbio.2010.05.031

Almagro M, Martínez-Mena M (2014) Litter decomposition rates of green manure as affected by soil erosion, transport and deposition processes, and the implications for the soil carbon balance of a rainfed olive grove under a dry Mediterranean climate. Agric Ecosyst Environ 196:167-177. https://doi.org/10.1016/j.agee.2014.06.027

Almagro M, García-Franco N, Martínez-Mena M (2017) The potential of reducing tillage frequency and incorporating plant residues as a strategy for climate change. Agr Ecosyst Environ 246:210-220. https://doi.org/10.1016/j.agee. 2017.05.016

Almagro M, Ruiz-Navarro A, Díaz-Pereira E, Albaladejo J, Martínez-Mena M (2021) Plant residue chemical quality modulates the soil microbial response related to decomposition and soil organic carbon and nitrogen stabilization in a rainfed Mediterranean agroecosystem. Soil Biol Biochem 156:108198. https://doi.org/10.1016/j.soilbio.2021. 108198

Álvaro-Fuentes J, Lóczy D, Thiele-Bruhn S, Zornoza R (2019). Handbook of plant and soil analysis for agricultural systems (Version 1.0). Zenodo. http://hdl.handle.net/10317/ 7611

Amundson R, Berhe AA, Hopmans JW, Olson C, Sztein AE, Sparks DL (2015) Soil and human security in the 21st century. Science 348:6235. https://doi.org/10.1126/scien ce. 1261071

Bond-Lamberty B, Thomson AM (2012) A global database of soil respiration data. Biogeosciences 7:1915-1926. https:// doi.org/10.5194/bg-7-1915-2010 
Bossio DA, Cook-Paton SC, Ellis PW et al (2020) The role of soil carbon in natural climate solutions. Nat Sustain 3:391-398. https://doi.org/10.1038/s41893-020-0491-z

Brilli L, Gioli B, Toscano P, Moriondo M, Zaldei A, Cantini C, Ferrise R, Bindi M (2016) Rainfall regimes control C-exchange of Mediterranean olive orchard. Agric Ecosyst Environ 233:147-157. https://doi.org/10.1016/j.agee. 2016.09.006

Burke W, Gabriels D, Bouma J (1986) Bulk density. In: Klute, A (ed), Methods of soil analysis. Part I. Am Soc Agron Madison, pp 363-376

Burke IC, Lauenroth WK, Coffin DP (1995) Soil organic matter recovery in semiarid grasslands: implications for the conservation reserve program. Ecol Appl 5:793-801. https://doi.org/10.2307/1941987

Cardinael R, Chevallier T, Guenet B, Girardin C, Cozzi T, Pouteau V, Chenu C (2020) Organic carbon decomposition rates with depth and contribution of inorganic carbon to $\mathrm{CO}_{2}$ emissions under a Mediterranean agroforestry system. Eur J Soil Sci 71:909-923. https://doi.org/10.1111/ ejss. 12908

Chamizo S, Serrano-Ortiz P, López-Ballesteros A, SánchezCañete EP, Vicente-Vicente JL, Kowalski AS (2017) Net ecosystem $\mathrm{CO} 2$ exchange in an irrigated olive orchard of SE Spain: Influence of weed cover. Agric Ecosyst Environ 239:51-64. https://doi.org/10.1016/j.agee.2017.01.016

Davidson EA, Belk E, Boone RD (1998) Soil water content and temperature as independent or confounded factors controlling soil respiration in a temperature mixed hardwood forest. Glob Chang Biol 4:217-227. https://doi.org/ 10.1046/j.1365-2486.1998.00128.x

Forrester DI, Bauhus J, Cowie AL (2006) Carbon allocation in a mixed-species plantation of Eucalyptus globulus and Acacia mearnsii. For Ecol Manage 233:275-284. https:// doi.org/10.1016/j.foreco.2006.05.018

Gaertig T, Schack-Kirchner H, Hildebrand EE, Wilpert KV (2002) The impact of soil aeration on oak decline in southwestern Germany. For Ecol Manage 159:15-25

García-Franco N, Martínez-Mena M, Goberna M, Albaladejo J (2015) Changes in soil aggregation and microbial community structure control carbon sequestration after afforestation of semiarid shrublands. Soil Biol Biochem 87:110121. https://doi.org/10.1016/j.soilbio.2015.04.012

García-Ruiz JM (2010) The effects of land uses on soil erosion in Spain: a review. CATENA 81:1-11. https://doi.org/10. 1016/j.catena.2010.01.001

Giardina CP, Ryan MG (2002) Total belowground carbon allocation in a fast-growing eucalyptus plantation estimated using a carbon balance approach. Ecosystems 5:487-499

Hancock GR, Lowry JBC (2015) Hillslope erosion measurement-a simple approach to a complex process. Hydrol Process 29:4809-4816. https://doi.org/10.1002/hyp.10608

Hashimoto S, Suzuki M (2002) Vertical distributions of carbon dioxide diffusion coefficients and production rates in forest soils. Soil Sci Soc Am J 66:1151. https://doi.org/10. 2136/sssaj2002.1151

Hillel D, Rosenzweig C (2011) The role of soils in climate change. In: Handbook of climate change and agroecosystems impacts, adaptation and mitigation, pp 9-20

Hutchinson JJ, Campbell CA, Desjardins RL (2007) Some perspectives on carbon sequestration in agriculture. Agric for
Meteorol 142:288-302. https://doi.org/10.1016/j.agrfo rmet.2006.03.030

IPCC (2019) Climate Change and Land: an IPCC special report on climate change, desertification, land degradation, sustainable land management, food security, and greenhouse gas fluxes in terrestrial ecosystems [Shukla PR, Skea J, Calvo Buendia E, Masson-Delmotte V, Pörtner H-O, Roberts DC, Zhai P, Slade R, Connors S, van Diemen R, Ferrat M, Haughey E, Luz S, Neogi S, Pathak M, Petzold, Portugal Pereira J, Vyas P, Huntley E, Kissick K, Belkacemi M, Malley J, (eds.). In press

IUSS Working Group WRB (2015) World reference base for soil resources 2014, Update 2015 international soil classification system for naming soils and creating legends for soil maps. World Soil Resources Reports No. 106. FAO, Rome

Kuzyakov Y (2002) Review: factors affecting rhizosphere priming effects. J Plant Nutr Soil Sci 165:382

Lal R (2008) Soil carbon stocks under present and future climate with specific reference to European ecoregions. Nutr Cycl Agroecosyst 81:113-127

López-Teloxa LC, Monterroso-Rivas AI (2020) Soil respiration in an agrosilvopastoral system in central Mexico. Trop Subtrop Agroecosyst 23:67

Martínez-Mena M, López J, Almagro M, Boix-Fayos C, Albaladejo J (2008) Effect of water erosion and cultivation on the soil carbon stock in a semiarid area of SouthEast Spain. Soil Tillage Res 99:119-129

Martínez-Mena M, Carrillo-López E, Boix-Fayos C, Almagro M, García Franco N, Díaz Pereira E, Montoya I, de Vente J (2020) Long-term effectiveness of sustainable land management practices to control runoff, soil erosion, and nutrient loss and the role of rainfall intensity in Mediterranean rainfed agroecosystems. CATENA 187:104352. https://doi.org/10.1016/j.catena.2019.104352

McCulley RL, Archer SR, Boutton TW, Hons FM, Zuberer DA (2004) Soil respiration and nutrient cycling in wooded communities developing in grassland. Ecology 85:2804-2817

Midwood AJ, Hannam KD, Forge TA, Neilsen D, Emde D, Jones MD (2020) Importance of drive-row vegetation for soil carbon storage in woody perennial crops: a regional study. Geoderma 377:114591. https://doi.org/10.1016/j. geoderma.2020.114591

Morugán-Coronado A, Linares C, Gómez-López MD, Faz A, Zornoza R (2020) The impact of intercropping, tillage and fertilizer type on soil and crop yield in fruit orchards under Mediterranean conditions: a meta-analysis of field studies. Agric Syst 178:102736. https://doi.org/10.1016/j. agsy.2019.102736

Nardino M, Pernice F, Rossi F, Georgiadis T, Facini O, Motisi A, Drago A (2013) Annual and monthly carbon balance in an intensively managed Mediterranean olive orchard. Photosynthetica 51:63-74

Ogle SME, Breidt FJ, Paustian K (2005) Agricultural management impacts on soil organic carbon storage under moist and dry climatic conditions of temperate and tropical regions. Biogeochemistry 72:87-121. https://doi.org/10. 1007/s10533-004-0360-2

Ordoñez-Fernández R, Rodriguez-Lizana A, Espejo-Perez AJ, Gonzalez-Fernández P, Milagros Saavedra M (2007) 
Soil and available phosphorus losses in ecological olive groves. Europ J Agron 27:144-153. https://doi.org/10. 1016/j.eja.2007.02.006

Owens LB, Malone RW, Horthem DL, Starr GC, Lal R (2002) Sediment carbon concentration and transport from small watersheds under various conservation tillage practices. Soil till Res 67:65-73. https://doi.org/10.1016/S01671987(02)00031-4

Palese AM, Pergola M, Favia M, Xiloyannis C (2013) A sustainable model for the management of olive orchards located in semi-arid marginal areas: some remarks and indications for policy makers. Environ Sci Policy 27:8190. https://doi.org/10.1016/j.envsci.2012.11.001

Pardo G, del Prado A, Alvaro-Fuentes J, Martínez-Mena M, Rodríguez Martín JA, Bustamante MA, Moral R (2017) Intensive orchard and horticulture systems in semi-arid Mediterranean agriculture: Is there a real possibility to contribute to $\mathrm{C}$ sequestration? Agric Ecosyst Environ 238:153-167. https://doi.org/10.1016/j.agee.2016.09.034

Paustian K, Lehmann J, Ogle S, Reay D, Robertson GP, Smith P (2016) Climate-smart soils. Nature 532:49-57. https:// doi.org/10.1038/nature17174

Pengthamkeerati P, Motavalli PP, Kremer RJ, Anderson SH (2006) Soil compaction and poultry litter effects on factors affecting nitrogen availability in a claypan soil. Soil Tillage Res 91:109-119. https://doi.org/10.1016/j.still. 2005.11.008

Perez-Quezada JF, Delpiano CA, Snyder KA, Johnson DA, Franck N (2011) Carbon pools in an arid shrubland in Chile under natural and afforested conditions. J Arid Environ 75:29-37. https://doi.org/10.1016/j.jaridenv.2010.08. 003

Ruiz I, Almagro M, García de Jalóna S, Solà M, Sanz MJ (2020) Assessment of sustainable land management practices in Mediterranean rural regions. J Environ Manage 276:111293. https://doi.org/10.1016/j.jenvman.2020. 111293

Quinton JN, Govers G, Van Oost K, Bardgett RD (2010) The impact of agricultural soil erosion on biogeochemical cycling. Nat Geosci 3:311-314. https://doi.org/10.1038/ ngeo838

Schlesinger WH (1986) Changes in soil carbon storage and associated properties with disturbance and recovery - The changing carbon cycle, pp 194-220

Smith P, Bustamante M, Ahammad H, Tubiello F (2014) Agriculture, forestry and other land use (AFOLU). In: Edenhofer O, Pichs-Madruga R, Sokona Y, Farahani E et al (eds) Climate Change 2014: mitigation of climate change. Contribution of working group III to the Fifth Assessment Report of the Intergovernmental Panel on Climate Change. Cambridge University Press, Cambridge, United Kingdom and New York, pp 811-922
Taguas EV, Gómez JA (2015) Vulnerability of olive orchards under the current CAP (Common Agricultural Policy) regulations on soil erosion: a study case in Southern Spain. Land Use Pol 42:683-694. https://doi.org/10. 1016/j.landusepol.2014.09.001

Tamburini G, Bommarco R, Wanger TC, Kremen C, van der Heijden MGA, Liebman M, Hallin S (2020) Agricultural diversification promotes multiple ecosystem services without compromising yield. Sci Adv 6:715

Tezza L, Vendramea N, Pitacco A (2019) Disentangling the carbon budget of a vineyard: the role of soil management. Agric Ecosyst Environ 272:52-62. https://doi.org/10. 1016/j.agee.2018.11.002

Vicente-Vicente JL, García-Ruiz R, Francaviglia R, Aguilera E, Smith P (2016) Soil carbon sequestration rates under Mediterranean woody crops using recommended management practices: a meta-analysis. Agric Ecosyst Environ 235:204-214. https://doi.org/10.1016/j.agee.2016.10.024

Wolff M, Alsina MM, Stockert CM, Darshan S, Khalsa S, Smart DR (2018) Minimum tillage of a cover crop lowers net GWP and sequesters soil carbon in a California vineyard. Soil Tillage Res 175:244-254. https://doi.org/10. 1016/j.still.2017.06.003

Xiao H, Li Z, Chang X, Huang B, Nie X, Liu C, Liu L, Wang D, Jiang L (2018) The mineralization and sequestration of organic carbon in relation to agricultural soil erosion. Geoderma 329:73-81. https://doi.org/10.1016/j.geoderma. 2018.05.018

Xu M, Qi Y (2001) Spatial and seasonal variation of Q10 determined by soil respiration measurements at a Sierra Nevada. Forest Glob Biogeochem Cycles 15:687-696. https://doi.org/10.1029/2000GB001365

Yoo K, Amundson R, Heimsath AM, Dietrich WE (2005) Erosion of upland hillslope soil organic carbon: coupling field measurements with a sediment transport model. Glob Biogeochem Cycles 19:1-17. https://doi.org/10.1029/2004G B002271

Zahra SI, Abbas F, Ishaq W, Ibrahim M, Hammad HM, Akram B, Salik MR (2016) Carbon sequestration potential of soils under maize production in irrigated agriculture of the Punjab province of Pakistan. J Anim Plant Sci 26:706-715

Publisher's note Springer Nature remains neutral with regard to jurisdictional claims in published maps and institutional affiliations. 